AperTO - Archivio Istituzionale Open Access dell'Università di Torino

\title{
Early changes of muscle IGF-1 and myostatin gene expression in gastric cancer patients
}

\section{This is the author's manuscript}

Original Citation:

Availability:

This version is available http://hdl.handle.net/2318/144645

since 2016-08-02T14:47:28Z

Published version:

DOI:10.1002/mus.23798

Terms of use:

Open Access

Anyone can freely access the full text of works made available as "Open Access". Works made available under a Creative Commons license can be used according to the terms and conditions of said license. Use of all other works requires consent of the right holder (author or publisher) if not exempted from copyright protection by the applicable law. 
This is the author's final version of the contribution published as:

A. Bonetto; F. Penna; Z. Aversa; P. Mercantini; F.M. Baccino; P. Costelli; V. Ziparo; S. Lucia; F. Rossi Fanelli; M. Muscaritoli. Early changes of muscle IGF-1 and myostatin gene expression in gastric cancer patients. MUSCLE \& NERVE. 48 (3) pp: 387-392.

DOI: $10.1002 /$ mus.23798

The publisher's version is available at:

http://doi.wiley.com/10.1002/mus.23798

When citing, please refer to the published version.

Link to this full text:

http://hdl.handle.net/2318/144645 


\section{EARLY CHANGES OF MUSCLE IGF-1 AND MYOSTATIN GENE EXPRESSION IN GASTRIC CANCER PATIENTS}

Andrea Bonetto $^{1^{*}}$, Fabio Penna ${ }^{1}$, Zaira Aversa ${ }^{2}$, Paolo Mercantini ${ }^{3}$, Francesco M. Baccino ${ }^{1}$, Paola Costelli ${ }^{1}$, Vincenzo Ziparo ${ }^{3}$, Simone Lucia $^{2}$, Filippo Rossi Fanelli ${ }^{2}$, Maurizio Muscaritoli

${ }^{1}$ Dipartimento di Medicina e Oncologia Sperimentale, Università di Torino, Italy

${ }^{2}$ Dipartimento di Medicina Clinica, Sapienza - Università di Roma, Italy

${ }^{3}$ Dipartimento di Chirurgia, Sapienza - Università di Roma, Italy

\section{Acknowledgements}

Work supported by 'Ministero per l'Università e la Ricerca' (Roma, Italy), University of Torino, Regione Piemonte, Associazione Italiana per la Ricerca sul Cancro (Milano, Italy), Fondazione San Paolo (Torino, Italy). ${ }^{*}$ Current affiliation: Department Cancer Biology, Kimmel Cancer Center - Thomas Jefferson University, Philadelphia, PA, USA

$\begin{array}{ll}\text { Corresponding author: } & \text { Prof. Maurizio Muscaritoli } \\ & \text { Dipartimento di Medicina Clinica, Sapienza - Università } \\ & \text { di Roma } \\ & \text { Viale dell'Università, } 37-00185 \text { Roma, Italy } \\ & \text { phone: }+39-06409972016 \\ & \text { fax: }+39-064461341 \\ & \text { maurizio.muscaritoli@uniroma1.it }\end{array}$

Running title: Myostatin and IGF-1 in gastric cancer 


\section{Abstract}

Introduction: Cachexia is a devastating condition that increases morbidity and mortality rates in cancer patients. It often becomes evident only at advanced disease stages, when responsiveness to currently available treatments may be limited or even absent. The progressive loss of muscle mass is by far the most prominent feature of cancer cachexia, negatively affecting physical function and quality of life. We previously reported that reduced IGF-1 expression and enhanced myostatin signaling in the muscle of tumor-bearing animals. The present study was aimed at investigating whether similar perturbations occur in gastric cancer patients as well.

Methods: Early perturbations of myostatin and IGF-1 signaling (including the expression of muscle-specific ubiquitin-ligases) were investigated in 16 gastric cancer patients and in 6 control subjects analyzing muscle mRNA expression by both semi-quantitative RT-PCR and real-time PCR.

Results: In gastric cancer patients, muscle mRNA levels for IGF-1, myostatin and atrogin1 were reduced while MuRF1 expression was unchanged. Changes occurred irrespective of weight loss $(\leq 5 \%$ or $>5 \%)$.

Discussion: The observation that IGF-1 and myostatin mRNA levels are down-regulated in gastric cancer patients with minimal or no weight loss indicates that molecular alterations in the skeletal muscle should be regarded as an early event in the course of the disease. This is particularly relevant in order to devise preventative and therapeutic strategies for cancer cachexia.

Key words: IGF-1; myostatin; ubiquitin ligases; human cancer; cachexia. 


\section{Introduction}

Patients with neoplastic disease frequently develop cachexia, a multifactorial syndrome defined by an ongoing loss of skeletal muscle mass (with or without loss of fat mass) and alterations of energy balance, driven by a variable combination of reduced food intake and abnormal metabolism. Conventional nutritional support cannot fully reverse this life-threatening pathological condition. ${ }^{1}$ Some of the causative factors had been identified, although the mechanisms underlying muscle protein hypercatabolism, one of the most important features of cachexia, still remain elusive. In particular, most of the information available about the pathogenesis of cachexia are derived from experimental studies, and very little is directly known about human cancer. Moreover, since cachexia often becomes clinically evident at a rather advanced disease stage, the detection of early subclinical perturbations that may be indicative of a situation of 'pre-cachexia" ${ }^{2,3}$ is important in order to take appropriate preventive measures to prevent the onset of overt cachexia.

Studies performed in the last decade led to unravel signaling pathways potentially contributing to the onset of muscle wasting. Particularly interesting, in this regard, are those regulated by Insulin-like growth factor (IGF)-1 and myostatin. The former is an anabolic growth factor known to stimulate protein synthesis rates in the skeletal muscle, as well as to induce satellite cells to proliferate and differentiate. ${ }^{4}$ Inhibition of apoptotic cell death and suppression of proteolysis, mainly due to down-regulation of the ubiquitinproteasome system are some of the effects exerted by IGF-1 on muscle tissue. ${ }^{5}$ In this regard, reduced IGF-1 circulating levels were reported in catabolic states such as cancer and sepsis..$^{6-8}$

Myostatin has been proposed to negatively regulate skeletal muscle mass. ${ }^{9}$ Muscle hypertrophy in cattles and humans has been reported to be associated with myostatin inactivating mutations. ${ }^{10,11}$ Consistently, increased muscle mass develops in mice when myostatin gene is disrupted, or the levels of active myostatin are low. Similarly, 
overexpression of a dominant negative form of the myostatin receptor ActRIIB, or administration of soluble ActRIIB lead to muscle hypertrophy. ${ }^{12,13}$ By contrast, high myostatin levels result in extensive skeletal muscle depletion. ${ }^{13,14}$ Myostatin protein levels are increased in ageing, denervation atrophy or mechanical unloading,$^{15}$ while reduced in the regenerative response induced in muscles by bupivacaine or notexin. ${ }^{16,17}$ Results from our laboratory demonstrate that myostatin signaling is enhanced in the skeletal muscle of tumor-bearing rats and mice ${ }^{18,19}$ and consistently, myostatin inhibition by antisense oligonucleotides, by administration of an ActRIIB/Fc fusion protein or and ActRIIB soluble form prevent muscle wasting in tumor-bearing mice..$^{20-22}$

Aim of the present study was to investigate whether early molecular perturbations occur in the skeletal muscle of gastric cancer patients. For this purpose, gene expression of myostatin, IGF-1 and muscle-specific ubiquitin ligases atrogin-1 and MuRF1 was evaluated.

\section{Material and methods}

\section{Patients}

Sixteen patients with gastric cancer admitted to the Department of Surgery, Second Faculty of Medicine, 'Sapienza' University of Rome, Italy, were included. The study was approved by the local ethical committee and written informed consent was obtained from all patients before enrolment in the study. Diagnosis of gastric cancer was made by endoscopic biopsy. Patients undergoing abdominal surgery for non-neoplastic diseases (inguinal hernia, laparocele, abdominal aorta aneurysm) served as controls $(n=6)$. Exclusion criteria for both groups were: liver failure, diabetes, acute or chronic renal failure, metabolic acidosis, AIDS, inflammatory bowel disease, autoimmune disorders, sepsis, chronic obstructive pulmonary disease, chronic heart failure, hepatitis, hyperthyroidism. Some of the subjects enrolled in the present study also participated in a 
previous investigation from our group. ${ }^{23}$ After an overnight fast, subjects were studied at 8:00 am. Nutritional assessment was performed by evaluating anthropometric parameters, usual body weight, percent weight loss, biochemical and immunological indices (see Table 1).

\section{Muscle biopsy}

A biopsy specimen was obtained from the rectus abdominis muscle during the initial phase of the operation. The anterior sheet of the rectus abdominis muscle was opened with scissors after skin incision and dissection through the subcutaneous fat, and a muscle biopsy specimen weighing about $0.5 \mathrm{~g}$ was obtained. The biopsy specimen was immediately frozen in liquid nitrogen and then stored at $-80^{\circ} \mathrm{C}$ until analysis. Small bleeding vessels were carefully controlled with ligatures and cautery after the muscle biopsy had been obtained, whereafter the operation continued in a routine fashion. No complications occurred from the biopsy procedure.

Reverse Transcription-PCR

Total RNA was extracted using the TriPure reagent (Roche, Indianapolis, IN, USA) and following manufacturer's instructions. RNA concentration was determined spectrophotometrically $(260 \mathrm{~nm})$, purity ensured by $260 / 280 \mathrm{~nm}$ ratio, and integrity checked by electrophoresis on $1.2 \%$ agarose gel, containing morpholino propane-sulfonic acid (MOPS) $0.02 \mathrm{M}$ and $18 \%$ formaldehyde (37\%).

mRNA levels of the analytes were determined by semiquantitative RT-PCR using the kit 'Ready-to-Go' (GE Healthcare, Milano, Italy). Primers for GAPDH, IGF-1, Myostatin, Atrogin-1 and MuRF1 were obtained according to published sequences (Table 2; Invitrogen, Milano, Italy). Retrotranscription was performed at $42^{\circ} \mathrm{C}$ for $30 \mathrm{~min}$. Amplification was run as specified in Table 2. Positive and negative controls were performed. PCR products (GAPDH = 497bp; IGF-1 = 184bp; Myostatin $=79 \mathrm{bp} ;$ Atrogin $-1=$ $168 \mathrm{bp} ;$ MuRF-1 $=225 \mathrm{bp}$ ) were electrophoresed on $2 \%$ agarose gels and visualized by 
staining with ethidium bromide. A 100bp-standard DNA ladder (Fermentas, Burlington, ON, Canada) was used to estimate PCR products length. Quantification was performed by densitometric analysis: individual product bands and representative background were excised from each gel lane and analyzed by means of a specific software (Phoretix). The results were normalized according to GAPDH expression (conditions of amplification reported in Table 2). Groups were compared in the linear range of amplification.

As for real-time PCR, a new RNA extraction was performed as reported above. RNA was quantified fluorimetrically using the Quant-iT RiboGreen reagent (Molecular Probes, Eugene, OR, USA). $0,5 \mu \mathrm{g}$ of total RNA were retro-transcribed to cDNA using the iScript cDNA Synthesis Kit (Bio-Rad, Hercules, CA, USA). Transcript levels were determined by using the SsoFast Evagreen Supermix and the MiniOpticon thermal cycler (Bio-Rad). 10 seconds of denaturation at $95^{\circ} \mathrm{C}$ were followed by 30 seconds of annealing/extension at $60^{\circ} \mathrm{C}$ and repeated for 40 cycles. Gene expression was normalized to both GAPDH and TBP expression (see Table 2 for primer sequences).

Data analysis and presentation

Results are expressed as mean \pm SEM. Significance of the differences was evaluated by Student's unpaired 't' test corrected according to Welch, as well as by a non-parametric test (Mann-Whitney), and were considered significant at $p<0.05$. Data obtained from the two tests were comparable.

\section{Results}

Subject characteristics are shown in Table 1. Mean age was $64 \pm 2.75$ years for patients and $62 \pm 5.71$ years for controls (data expressed as means $\pm S E M$ ). Body weight loss $<5 \%$ was detectable in 8 out of the 16 patients (50\%), while median weight loss of the whole group ( $n=16$ ) was $5.45 \%$ (see ref. 2 ). As for clinical parameters, only haemoglobin 
levels were significantly decreased in cancer patients with respect to control values (Table 1). Such reduction did not correlate with body weight loss and muscle gene expression.

IGF-1 mRNA expression in the skeletal muscle of gastric cancer patients was markedly reduced $(70 \%$ of controls; $p<0.05$; figure $1 \mathrm{~A})$, even more when real-time PCR was used (controls $=1 \pm 1.693$, patients $=0.62 \pm 1.46$; normalized fold expression, $p<0.05$; figure 1B). The reduction was maintained also when patients were stratified according to weight loss ( $<5 \%$ : $72 \%$ of controls; $>5 \%$ : $76 \%$ of controls; performed on RTPCR data), while IGF-1 expression was comparable in stage I-II or III-IV patients (stage III: $0.34 \pm 0.03, n=12$; stage III-IV: $0.36 \pm 0.02, n=4$ ).

Muscle myostatin mRNA expression was markedly and significantly $(p<0.001)$ reduced with respect to control subjects (figure $2 \mathrm{~A}$ and $2 \mathrm{~B}$ ), irrespective of body weight loss ( $<5 \%$ : $49 \%$ of controls; $>5 \%: 47 \%$ of controls). Also for myostatin, the reduction observed in real-time PCR is more marked (controls $=1 \pm 1.79$, patients $=0.30 \pm 1.18$; normalized fold expression, $p<0.001$; figure $2 B$ ). No differences were observed when patients were stratified according to tumor stage (stage I-II: $0.46 \pm 0.04, \mathrm{n}=12$; stage IIIIV: $0.37 \pm 0.01, n=4)$. In addition, no correlation with IGF-1 expression was observed (Spearman test: $r=0.336, p=0.240$ ).

Gene expression for both atrogin-1 and MuRF1 in gastric patients and controls is shown in figure 3. Atrogin-1 expression was $45 \%$ of controls $(p<0.001)$. Such observation, however, was not confirmed by real-time PCR, that revealed only a tendency to reduction, not statistically significant (controls $=1 \pm 1.41$, patients $=0.74 \pm 1.35$; normalized fold expression, $p=0.817$ ). As for MuRF1, no significant differences were observed between controls and cancer patients, although real-time PCR revealed a tendency to increase that did not reach significance (controls $=1 \pm 1.23$, patients $=1.42 \pm 1.27$; normalized fold expression, $p=0.296$ ). Stratification according to body weight loss lead to comparable results for both ubiquitin ligases (atrogin- 1 : $<5 \%=49 \%$ of controls, $>5 \%=45 \%$ of controls; 
MuRF1: $<5 \%=118 \%$ of controls, $>5 \%=112 \%$ of controls). Ubiquitin ligase expression was not changed in stage I-II compared with stage III-IV patients (Atrogin-1: stage I-II, 0.41 $\pm 0.04, \mathrm{n}=12$; stage III-IV, $0.51 \pm 0.08, \mathrm{n}=4$. MuRF1: stage I-II, $0.38 \pm 0.01, \mathrm{n}=12$; stage III-IV, $0.36 \pm 0.03, \mathrm{n}=4)$.

\section{Discussion}

The results obtained in the present study show that, similarly to experimental cachexia, IGF-1 mRNA expression is significantly reduced in the skeletal muscle of gastric cancer patients.

This is the first study reporting that IGF-1 mRNA levels are decreased in the muscle of cancer patients, supporting the hypothesis that a down-regulation of the IGF-1 signaling is involved also in the pathogenesis of human cancer cachexia. Interestingly, such reduction is detectable either when patients are pooled together, or when they are stratified according to body weight loss $(<5 \%$ or $>5 \%)$. This is an important finding since it further confirms that observations made in experimental models may well apply to human cancer. Moreover, similar observations showing a marked down-regulation of IGF-1 and IGF-binding proteins 3, 4 and 5 despite an increase in IGF-1R expression have been reported in a study conducted on patients affected by sporadic amyotrophic lateral sclerosis $^{24}$. However, such a view cannot be generalized. Indeed, the expression levels of muscle myostatin mRNA, which have been shown to be enhanced in tumor-bearing animals, are significantly reduced in gastric cancer patients. This result appears particularly surprising as we previously reported an increase in myostatin protein level in gastric cancer patients. ${ }^{23}$ Although the reason for these apparently contradictory results is not known at present, the differences may at least in part be due to post-transcriptional mechanisms such as increased myostatin synthesis secondary to increased translational efficiency or reduced degradation of myostatin. Interestingly enough a similar discrepancy 
between myostatin mRNA and protein levels have been previously reported in other conditions associated to muscle atrophy. ${ }^{25,26}$ It should be noted, however, that most of the patients included in the present study were in disease stages 1 or 2 . It cannot be excluded that myostatin perturbations may become apparent in more advanced stages of the disease when more significant weight loss and cachexia occur. Further research in this respect is warranted. Finally, reduced myostatin mRNA might reflect an early compensatory response activated by the muscle to maintain the homeostasis.

Previous results from our laboratories showed that hyperactivation of the ATPubiquitin-dependent proteolytic system is an early event in the skeletal muscle of gastric cancer patients. Indeed, both ubiquitin mRNA expression and proteasome enzymatic activities were found significantly elevated before any evidence of body weight loss. ${ }^{23,27}$ In the present study the expression of muscle-specific ubiquitin ligases atrogin-1 and MuRF1 was assessed. As for IGF-1 and myostatin, also atrogin-1 and MuRF1 expression was evaluated by both RT-PCR and real-time PCR. While both techniques gave qualitatively comparable results for IGF-1 and myostatin, the data obtained for atrogin-1 and MuRF1 were slightly different. Indeed, the significant reduction of atrogin-1 mRNA levels when evaluated by RT-PCR was no more evident by real-time PCR, although a tendency to decrease occurred. Similarly, MuRF1 expression was unchanged in cancer patients with respect to controls, whether evaluated by RT-PCR or by real-time PCR, although the latter showed a tendency to increase. On the whole, our conclusion is that muscle-specific ubiquitin ligase gene expression is not significantly modified in cancer hosts, at least in the present group of patients. Such observations agree with those reported by a previous study showing that atrogin-1 and MuRF1 gene expression in gastric cancer patients was not significantly affected, despite a trend toward increase occurred. ${ }^{28}$

The reasons for these inconsistencies remain so far unknown, underscoring the need for further studies aimed at clarifying whether increased mRNA expression for 
ubiquitin ligases may really be considered a molecular marker of muscle atrophy also in human diseases associated with muscle loss. In this regard, muscle atrophy in patients affected by spinal cord injury is associated with low expression of IGF-1, MuRF1 and atrogin- $1 .{ }^{29}$ However, it cannot be excluded that in human cancer cachexia a significant increase in atrogin-1 and MuRF1 mRNA levels may occur with greater rates of weight loss. This hypothesis is supported by the observation that reduced expression of proteasome subunits was not apparent in cancer patients with weight loss $<10 \% .{ }^{30}$ Indeed gastric cancer patients included in the present study presented only minimal or no weight loss.

Interestingly, in the present study, no increase of atrogin-1 mRNA levels could be detected, either by RT-PCR or by real-time PCR. Although this finding is somehow surprising, it should be noted that pharmacological correction of muscle wasting in cancer cachexia is not always paralleled by changes in atrogin- 1 expression. ${ }^{7,31}$ This observation suggests that changes of muscle mass and atrogin-1 mRNA levels might not be tightly coupled. This hypothesis is also consistent with another report showing that restoration of normal atrogin-1 expression induced in fasted or diabetic rats by IGF-1 treatment was not associated with muscle mass recovery. ${ }^{32}$ In addition, reduced protein degradation rates resulting from incubation of muscles isolated from burned rats in the presence of GSK3- $\beta$ inhibitors was reported to occur irrespective of changes in atrogin-1 mRNA levels. ${ }^{33}$ Finally, there are no available reports demonstrating a correlation between ubiquitin ligase mRNA levels and proteasome enzymatic activity. Based on these observation, Attaix and Baracos recently proposed that "atrogin-1 expression is a poor index of muscle proteolysis". $^{34}$

In conclusion, although the sample size might represent a limitation, the present study shows for the first time that both IGF-1 and myostatin mRNA expression are reduced in the skeletal muscle of gastric cancer patients and suggests that the down-regulation of muscle IGF-1 and myostatin gene expression is an early event in the course of the 
disease. Further studies are warranted to understand whether such alterations persist or if a different modulation in the expression of these genes may occur in advanced disease stages associated with greater body weight loss. 
Disclosure statement

The authors declare no conflict of interest

Abbreviations:

IGF-1, Insulin-like growth factor 1; mIGF-1, isoform of IGF-1 in the skeletal muscle. 


\section{References}

1. Argilés JM, Anker SD, Evans WJ, Morley JE, Fearon KC, Strasser F, et al. Consensus on cachexia definitions. J Am Med Dir Assoc. 2010; 11(4): 229-230.

2. Fearon K, Strasser F, Anker SD, Bosaeus I, Bruera E, Fainsinger RL, et al., Definition and classification of cancer cachexia: an international consensus. Lancet Oncol. 2011; 12(5): 489-495.

3. Muscaritoli M, Anker SD, Argilés J, Aversa Z, Bauer JM, Biolo G, et al. Consensus definition of sarcopenia, cachexia and pre-cachexia: joint document elaborated by Special Interest Groups (SIG) "cachexia-anorexia in chronic wasting diseases" and "nutrition in geriatrics". Clin Nutr. 2010; 29(2): 154-159.

4. Florini JR, Samuel DS, Ewton DZ, Kirk C, Sklar RM. Stimulation of myogenic differentiation by a neuregulin, glial growth factor 2 . Are neuregulins the long-sought muscle trophic factors secreted by nerves? J Biol Chem. 1996; 271(22): 12699_ 12702.

5. Duan C, Ren H, Gao S. Insulin-like growth factors (IGFs), IGF receptors, and IGFbinding proteins: roles in skeletal muscle growth and differentiation. Gen Com Endocrinol. 2010; 167(3): 344-51.

6. Attard-Montalto SP, Camacho-Hübner C, Cotterill AM, D'Souza-Li L, Daley S, Bartlett K, et al. Changes in protein turnover, IGF-I and IGF binding proteins in children with cancer. Acta Paediatr. 1998; 87(1):54-60.

7. Costelli P, Muscaritoli M, Bossola M, Penna F, Reffo P, Bonetto A, et al. IGF-1 is downregulated in experimental cancer cachexia. Am J Physiol Regul Integr Comp Physiol. 2006; 291(3): R674-R683.

8. Fan J, Molina PE, Gelato MC, Lang CH. Differential tissue regulation of insulin-like growth factor-I content and binding proteins after endotoxin. Endocrinology. 1994; 134(4): 1685-1692. 
9. Lee SJ, McPherron AC. Regulation of myostatin activity and muscle growth. Proc Natl Acad Sci USA. 2001; 98(16): 9306-9311.

10. McPherron AC, Lee SJ. Double muscling in cattle due to mutations in the myostatin gene. Proc Natl Acad Sci USA. 1997; 94 (23):12457-12461.

11. Schuelke M, Wagner KR, Stolz LE, Hübner C, Riebel T, Kömen W, et al. Myostatin mutation associated with gross muscle hypertrophy in a child. N Engl J Med. 2004; 350(26): 2682-2688.

12. Tsuchida K, Nakatani M, Uezumi A, Murakami T, Cui X. Signal transduction pathway through activin receptors as a therapeutic target of musculoskeletal diseases and cancer. Endocr J. 2008; 55(1): 11-21.

13. Tsuchida K, Targeting myostatin for therapies against muscle-wasting disorders. Curr Opin Drug Discov Devel. 2008; 11(4): 487-494.

14. Reisz-Porszasz S, Bhasin S, Artaza JN, Shen R, Sinha-Hikim I, Hogue A, et al. Lower skeletal muscle mass in male transgenic mice with muscle-specific overexpression of myostatin. Am J Physiol Endocrinol Metab. 2003; 285(4): E876E888.

15. Bradley L, Yaworsky PJ, Walsh FS. Myostatin as a therapeutic target for musculoskeletal disease. Cell Mol Life Sci. 2008; 65(14): 2119-2124.

16. Baumann AP, Ibebunjo C, Grasser WA, Paralkar VM. Myostatin expression in age and denervation-induced skeletal muscle atrophy. J Musculoskelet Neuronal Interact. 2003; 3(1): 8-16.

17. Kirk S, Oldham J, Kambadur R, Sharma M, Dobbie P, Bass J. Myostatin regulation during skeletal muscle regeneration. J Cell Physiol. 2000 ;184(3) : 356-363.

18. Bonetto A, Penna F, Minero VG, Reffo P, Bonelli G, Baccino FM, et al. Deacetylase inhibitors modulate the myostatin/follistatin axis without improving cachexia in tumor-bearing mice. Curr Cancer Drug Targets. 2009; 9(5): 608-616. 
19. Costelli P, Muscaritoli M, Bonetto A, Penna F, Reffo P, Bossola M, et al. Muscle myostatin signalling is enhanced in experimental cancer cachexia. Eur J Clin Invest. 2008; 38(7): 531-538.

20. Benny Klimek ME, Aydogdu T, Link MJ, Pons M, Koniaris LG, Zimmers TA. Acute inhibition of myostatin-family proteins preserves skeletal muscle in mouse models of cancer cachexia. Biochem Biophys Res Commun. 2010; 391(3): 1548-1554.

21. Liu CM, Yang Z, Liu CW, Wang R, Tien P, Dale R, et al. Effect of RNA oligonucleotide targeting Foxo-1 on muscle growth in normal and cancer cachexia mice. Cancer Gene Ther. 2007; 14(12): 945-952.

22. Zhou X, Wang JL, Lu J, Song Y, Kwak KS, Jiao Q, et al. Reversal of Cancer Cachexia and Muscle Wasting by ActRIIB Antagonism Leads to Prolonged Survival. Cell. 2010; 142(4): 531-543.

23. Aversa Z, Bonetto A, Penna F, Costelli P, Di Rienzo G, Lacitignola A, et al. Changes in myostatin signaling in non-weight-losing cancer patients. Ann Surg Oncol. 2012; 19(4): 1350-1356

24. Lunetta C, Serafini M, Prelle A, Magni P, Dozio E, Ruscica M, et al. Impaired expression of insulin-like growth factor-1 system in skeletal muscle of amyotrophic lateral sclerosis patients. Muscle Nerve. 2012; 45(2): 200-208.

25. Baumann AP, Ibebunjo C, Grasser WA, Paralkar VM. Myostatin expression in age and denervation-induced skeletal muscle atrophy. J Musculoskelet Neuronal Interact. 2003; 3(1): 8-16

26. Smith IJ, Aversa Z, Alamdari N, Petkova V, Hasselgren PO. Sepsis downregulates myostatin mRNA levels without altering myostatin protein levels in skeletal muscle. J Cell Biochem. 2010; 111(4): 1059-1073 
27. Bossola M, Muscaritoli M, Costelli P, Grieco G, Bonelli G, Pacelli F, et al. Increased muscle proteasome activity correlates with disease severity in gastric cancer patients. Ann. Surg. 2003; 237(3): 384-389.

28. Smith IJ, Aversa Z, Hasselgren PO, Pacelli F, Rosa F, Doglietto GB, et al. Calpain activity is increased in skeletal muscle from gastric cancer patients with minimal or no weight loss. Muscle Nerve. 2011; 43(3): 410-414

29. Léger B, Senese R, AI-Khodairy AW, Dériaz O, Gobelet C, Giacobino JP,et al. Atrogin-1, MuRF1, and FoXO, as well as phosphorylated GSK-3beta and 4E-BP1 are reduced in skeletal muscle of chronic spinal cord-injured patients. Muscle Nerve. 2009; 40(1): 69-79.

30. Khal J, Hine AV, Fearon KC, Dejong CH, Tisdale MJ. Increased expression of proteasome subunits in skeletal muscle of cancer patients with weight loss. Int $\mathrm{J}$ Biochem Cell Biol. 2005; 37(10): 2196-2206.

31. Mastrocola R, Reffo P, Penna F, Tomasinelli CE, Boccuzzi G, Baccino FM, et al. Muscle wasting in diabetic and tumor-bearing rats: role of oxidative stress. Free Radic Biol Med. 2008; 44(4): 584-593.

32. Dehoux M, Van Beneden R, Pasko N, Lause P, Verniers J, Underwood L, et al. Role of the insulin-like growth factor I decline in the induction of atrogin-1/MAFbx during fasting and diabetes. Endocrinology. 2004; 145(11): 4806-4812.

33. Fang CH, Li BG, James JH, King JK, Evenson AR, Warden GD, et al. Protein breakdown in muscle from burned rats is blocked by insulin-like growth factor 1 and glycogen synthase kinase-3beta inhibitors. Endocrinology. 2005; 146(7): 31413149.

34. Attaix D, Baracos VE. MAFbx/Atrogin-1 expression is a poor index of muscle proteolysis. Curr Opin Clin Nutr Metab Care. 2010; 13(3): 223-224. 


\section{Figure legends}

Figure 1 IGF-1 mRNA levels in the rectus abdominis muscle of gastric cancer patients.

(A) Pattern of IGF-1 expression evaluated by semi-quantitative RT-PCR. Upper panel: data (means \pm SEM, $n=16$ ) expressed as percentage of controls $(\mathrm{C}=0.46 \pm 0.14)$. Significance of the differences: ${ }^{*} \mathrm{p}<0.05$ vs controls $(n=6)$. Lower panel: representative RT-PCR pattern; (B) IGF-1 expression evaluated by real-time PCR. Data are normalized fold expression (means \pm SEM; controls: $n=3$; patients: $n=8$ ). Significance of the differences: ${ }^{*} p<0.05$ vs controls.

Figure 2 Myostatin mRNA levels in the rectus abdominis muscle of gastric cancer patients.

(A) Pattern of myostatin expression evaluated by semi-quantitative RT-PCR. Upper panel: data (means \pm SEM, $n=16$ ) expressed as percentage of controls $(\mathrm{C}=0.91 \pm 0.26)$. Significance of the differences: ${ }^{* \star *} \mathrm{p}<0.001 \mathrm{vs}$ controls $(n=6)$. Lower panel: representative RT-PCR pattern. (B) Myostatin expression evaluated by real-time PCR. Data are normalized fold expression (means \pm SEM; controls: $n=3$; patients: $n=8$ ). Significance of the differences: ${ }^{* \star *} \mathrm{p}<0.001$ vs controls.

Figure 3 Expression of atrogin-1 and MuRF1 in the rectus abdominis muscle of gastric cancer patients.

Upper panel: densitometric analysis. Data (means \pm SEM; $n=16$ ) expressed as percentage of controls (Atrogin-1: $\mathrm{C}=0.91 \pm 0.26$; MuRF1: $\mathrm{C}=0.33 \pm 0.14$ ). 
Significance of the differences: ${ }^{* *} p<0.001$ vs controls $(n=6)$. Lower panel: representative RT-PCR pattern.

\section{Table legends}

Table 1: Characteristics of the subjects studied. Values are expressed as means \pm SEM; ${ }^{*} p<0.05$ vs. controls.

Table 2: Oligonucleotide sequences used for semiquantitative reverse-transcriptase PCR (table 1A) and Real-time PCR (table 1B). The same oligonucleotides for IGF-1, Myostatin, Atrogin-1 and MuRF1 were used for both reverse transcriptase and Real-time PCR. The amplification protocols used for semiquantitative reverse-transcriptase PCR are indicated in table $1 \mathrm{~A}$. 
Table 1.

\begin{tabular}{|l|c|c|}
\hline & Controls & Patients \\
\hline Subjects & \multicolumn{2}{|c|}{} \\
\hline $\mathrm{n}$ & 6 & 16 \\
\hline Age, years & $62 \pm 5.71$ & $64 \pm 2.75$ \\
\hline Type & - & 14 \\
\hline Adenocarcinoma $(\mathrm{n})$ & - & 2 \\
\hline Lymphoma $(\mathrm{n})$ & - & 12 \\
\hline Stage & - & 4 \\
\hline I-II & \multicolumn{2}{|}{} \\
\hline III-IV & \multicolumn{2}{|}{} \\
\hline Anthropometric parametrs & $0.5 \pm 0.04$ & $5.3 \pm 1.22$ \\
\hline Percent weight loss & $26.2 \pm 2.08$ & $28.7 \pm 1.07$ \\
\hline Body Mass Index & $66.7 \pm 1.84$ & $64.8 \pm 1.4$ \\
\hline Serum total protein $(\mathrm{g} / \mathrm{L})$ & $36.2 \pm 1.59$ & $35.1 \pm 1$ \\
\hline Serum albumin $(\mathrm{g} / \mathrm{L})$ & $0.94 \pm 0.08$ & $0.90 \pm 0.02$ \\
\hline Serum creatinine $(\mathrm{mg} / \mathrm{dL})$ & $14.2 \pm 0.86$ & $11.0 \pm 0.85^{*}$ \\
\hline Hemoglobin $(\mathrm{g} / \mathrm{dL})$ & $6.9 \pm 0.86$ & $6.5 \pm 0.4$ \\
\hline White cell count $\left(\mathrm{x} 10^{3} / \mathrm{cmm}\right)$ & $2.41 \pm 0.45$ & $1.77 \pm 0.2$ \\
\hline Total lymphocyte count $\left(\mathrm{x} 10^{3} / \mathrm{cmm}\right)$ &
\end{tabular}


Table 2.

A. Reverse transcriptase-PCR

\begin{tabular}{|c|c|c|c|}
\hline Gene & Primer sequence & Amplification & Cycles \\
\hline $\begin{array}{c}\text { GAPDH } \\
\left(N M \_002046.3\right)\end{array}$ & $\begin{array}{l}\text { FW: GGTGAAGGTCGGAGTCAACG } \\
\text { RW: CAAAGTTGTCATGGATGACC }\end{array}$ & $\begin{array}{ll}1^{\prime} & 94^{\circ} \mathrm{C} \\
1^{\prime} & 55^{\circ} \mathrm{C} \\
1^{\prime} & 72^{\circ} \mathrm{C}\end{array}$ & 24 \\
\hline $\begin{array}{c}\text { IGF-1 } \\
\left(N M \_001111283.1\right)\end{array}$ & $\begin{array}{l}\text { FW: CAGCAGTCTTCCAACCCAAT } \\
\text { RW: CACGAACTGAAGAGCATCCA }\end{array}$ & $\begin{array}{cc}30^{\prime \prime} & 94^{\circ} \mathrm{C} \\
1^{\prime} & 60^{\circ} \mathrm{C} \\
1^{\prime} & 72^{\circ} \mathrm{C}\end{array}$ & 35 \\
\hline $\begin{array}{l}\text { Myostatin } \\
\left(N M \_005259.2\right)\end{array}$ & $\begin{array}{c}\text { FW: TGGTCATGATCTTGCTGTAACCTT } \\
\text { RW: TGTCTGTTACCTTGACCTCTAAAAACG }\end{array}$ & $\begin{array}{ll}1^{\prime} & 95^{\circ} \mathrm{C} \\
1^{\prime} & 60^{\circ} \mathrm{C} \\
1^{\prime} & 72^{\circ} \mathrm{C}\end{array}$ & 35 \\
\hline $\begin{array}{l}\text { Atrogin-1 } \\
\text { (NM_058229.2) }\end{array}$ & $\begin{array}{l}\text { FW: TCACAGCTCACATCCCTGAG } \\
\text { RW: AGACTTGCCGACTCTTTGGA }\end{array}$ & $\begin{array}{ll}1^{\prime} & 95^{\circ} \mathrm{C} \\
1^{\prime} & 58^{\circ} \mathrm{C} \\
1^{\prime} & 72^{\circ} \mathrm{C}\end{array}$ & 25 \\
\hline $\begin{array}{c}\text { MuRF-1 } \\
\left(N M \_032588.2\right)\end{array}$ & $\begin{array}{l}\text { FW: TGAGCCAGAAGTTTGACACG } \\
\text { RW: TGATGAGTTGCTTGGCAGTC }\end{array}$ & $\begin{array}{l}1^{\prime} \quad 95^{\circ} \mathrm{C} \\
1^{\prime} \quad 58^{\circ} \mathrm{C} \\
1^{\prime} \quad 72^{\circ} \mathrm{C}\end{array}$ & 25 \\
\hline
\end{tabular}

B. Real-time PCR

\begin{tabular}{|c|c|}
\hline Gene & Primer sequence \\
\hline $\begin{array}{c}\text { GAPDH } \\
\text { (NM_002046.3) }\end{array}$ & FW: CCACTCCTCCACCTTTGAC \\
\hline RBP & FW: ACCCTGTTGCTGTAGCCA \\
\hline (NM_003194) & RW: CACATCACAGGAGCCAAGAGTGAA \\
\hline
\end{tabular}


Figure 1
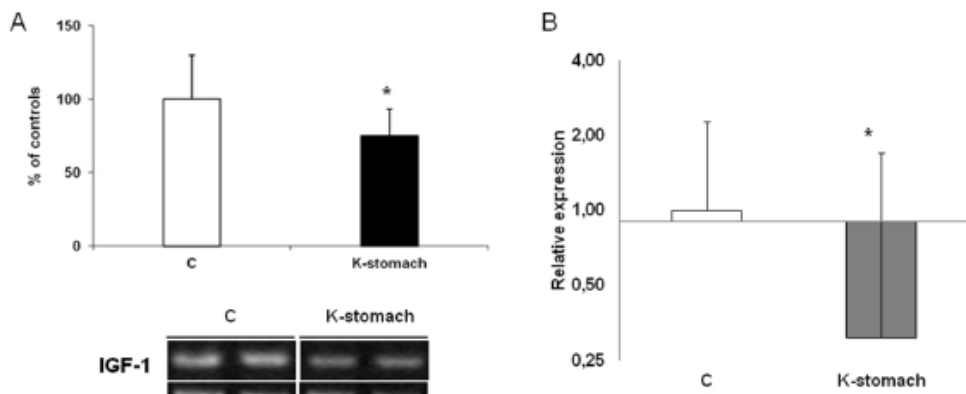

Figure 2

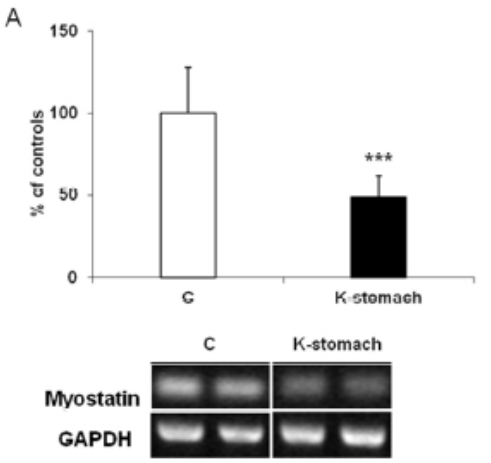

B

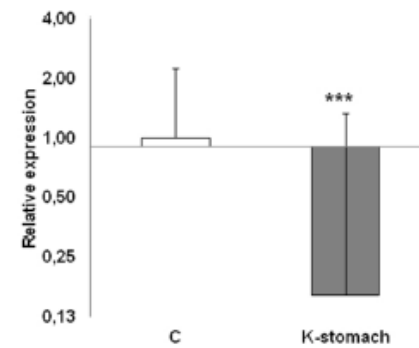


Figure 3

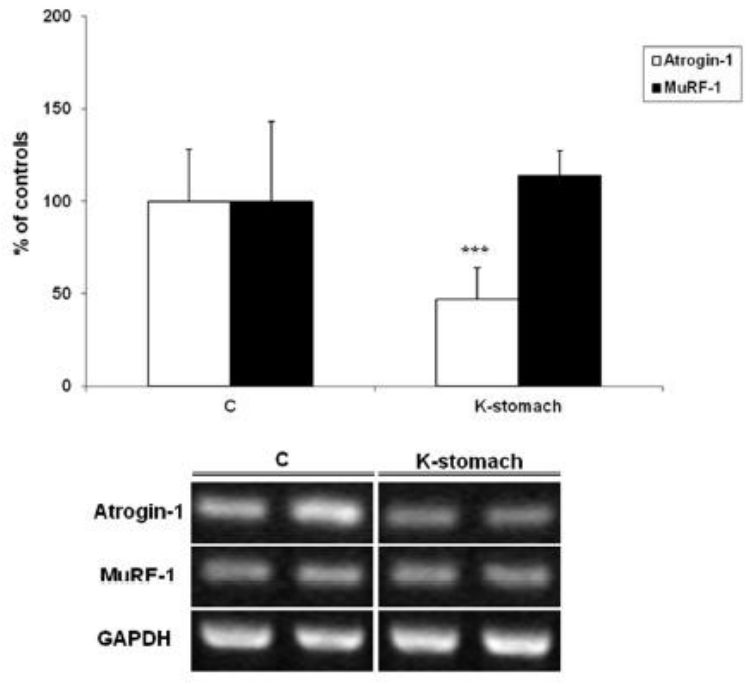

